\title{
PHYSICAL PROPERTIES OF PALMYRA PALM WOOD FOR SUSTAINABLE UTILIZATION AS A STRUCTURAL MATERIAL
}

\author{
James Boakye Acheampong ${ }^{1, \$}$ \\ https://orcid.org/0000-0003-2863-2993 \\ Bernard Effah ${ }^{2}$ \\ https://orcid.org/0000-0002-4032-0303 \\ Kwaku Antwi \\ https://orcid.org/0000-0001-7463-0265 \\ Ernest Wenia Achana ${ }^{4}$ \\ https://orcid.org/0000-0002-8466-815X
}

\begin{abstract}
Physical properties are major characteristics that validate biomaterials' adaptability to commercial utilization. The moisture content, density, swelling, and shrinkage within male and female Borassus aethiopum were assessed. Green and dry moisture content, and density were tested with the oven-dry method while swelling and shrinkage were evaluated using the water-saturation test and oven-dry methods respectively. Unlike moisture content, density decreased towards the crowns and radially from the peripheries to their cores. Directional swelling decreased as: Radial $>$ Tangential $>$ Longitudinal. Volumetric swelling was greatest at the core of the base $(6,99 \%)$ but at least at the periphery within the middle of the male $(2,89 \%)$. However, the female recorded much swelling at the core of its mid-portion $(6,23 \%)$ and least $(4,01 \%)$ at the crown periphery. Directional shrinkage decreased identically as the male variety while the volumetric shrinkage for both varieties was not consistent. The peripheries had less moisture content, better dimensional stability and density (which influences wood strength) at the butt than those of the core indicating the peripheries would maintain its original dimension and strength when subjected to environmental changes and be more viable for structural works than the core.
\end{abstract}

Keywords: Borassus aethiopum, density, dimensional, moisture, palmyra, stability, structural.

\footnotetext{
${ }^{1}$ University of Science and Technology, Faculty of Renewable Natural Resources, Department of Wood Science and Technology, Kwame Nkrumah Kumasi, Ghana.

${ }^{2}$ Kumasi Technical University, Department of Interior Design and Materials Technology, Kumasi, Ghana.

${ }^{3}$ Tamale Technical University, Department of Wood Technology, Tamale, Ghana.

${ }^{4}$ University of Education, Department of Construction and Wood Technology Education, Winneba, Kumasi, Ghana.

•Corresponding author: jbacheampong@yahoo.com

Received: 18.08.2021 Accepted: 05.11.2021
} 


\section{INTRODUCTION}

Tropical forests contain more species and biomass than any other biome on earth but they are being rapidly deforested and degraded. Forests contribute immensely to societies, economies, and human well-being, providing vital services that can sustain generations. The global demand for tropical commercial timbers has led to large volumes harvested over the past decades, which makes them a major export earner to countries such as Ghana. Thus, the rate at which evergreen forest timber species are diminishing is very alarming (about 2 $\%$ per year) such that meeting the needs of the future generations seem bleak (Tropenbos International-Ghana 2005, Watson et al. 2018, Phillips et al. 2019). The over-exploitation and depletion of forest timber resources call for research into alternative timber species such as Non-Timber Forest Products (NTFPs), which are in abundance but scarcely tap (Chamberlain et al. 2000). This could reduce the over-dependence on the primary timber species of commercial importance, ensure forest sustainability, and promote the economic utilization of the NTFPs. Borassus aethiopum Mart., commonly called African fan palm or Palmyra Palm, is NTFP, a monocotyledonous and dioecious palm of the family Palmae or Arecaceae (Jatau 2008). It is fairly straight and grows between $7 \mathrm{~m}-20 \mathrm{~m}$, sometimes $30 \mathrm{~m}$ tall and considered as Africa's tallest palm characterized by a crown up to $8 \mathrm{~m}$ wide. Young Borassus aethiopum palms are covered with dry leaf stalks, showing gradual fading leaf scars. However, at over 25 years old, they produce swelling trunks of $12 \mathrm{~m}-15 \mathrm{~m}$ above the ground with pale, grey bark in older palms, which are more or less smooth. Two varieties of Borassus aethiopum (i.e., the male and female) exist. They are solitary, pleonanthic (i.e., they do not die after flowering) and have a straight trunk diameter of $40 \mathrm{~cm}-50 \mathrm{~cm}$ and bulge usually after 25 years of growing up to $80 \mathrm{~cm}$ across the middle (Millennium Seed Bank Project 2007). The male bears flowers but does not produce fruits for consumption, while the female bear fruits between 50 and 150 every 8 months for consumption and medicinal purposes. A cross-section through each stem shows three layers: the dermal (periphery), subdermal (core), and central. They are multi-purpose palm with multi-functional importance, as every part can serve socio-cultural, economic, and environmental needs (Asafu-Adjaye 2011, Acheampong et al. 2020).

Wood versatility is demonstrated by a wide variety of products as a result of a spectrum of desirable physical characteristics within timber species (Bowyer et al. 2003). Wood, as a hygroscopic material, depends on external conditions to absorb or release moisture. The moisture relationship has an important influence on wood properties and performance. Many of the challenges of using wood as an engineering material arise from changes in moisture content (MC) or an abundance of moisture within the wood. This movement of moisture on the hygroscopic level is accompanied by swelling and shrinkage. The anisotropic properties of wood are manifested through the different degrees of swelling and shrinkage (dimensional stability) in the individual anatomic directions (Glass and Zelinka 2010).

Wood is sensitive to humidity due to its hydrophilic constituent of polymers such as cellulose, hemicelluloses, and lignin. The MC of wood varies with the changes in temperature and humidity of the surrounding below Fiber Saturation Point (FSP). The dimensional changes that occur due to the swelling and shrinking of wood cause significant practical problems in wood utilization for building and construction (Ajuziogu et al. 2020, Eckelman 2020). The variability in dimensional stability among wood species is partly due to the structural organization of cells in addition to their chemical composition. Dimensional stability has been recognized as a potential technological wood characteristic to validate whether a wood species is applicable for commercial utilization such as flooring, paneling, doors and windows, furniture, and roofing members in contact with variations in MC and temperature. Dimensional changes cause wood defects (e.g. warping, splitting, bowing, fracture, checking, case-hardening, and honey-combing), the opening of woodwork joints, and the loosening of fasteners, which reduce the quality of timber products and affect their usage. study sought to investigate the MC, density, swelling, and shrinkage within the two varieties of Borassus aethiopum, as a structural material for the Wood Industry. The specimen for study were randomly taken from the base, middle, and crown along the boles. The baseline information would contribute to the understanding of the behavior of woody palms when in contact with moisture and the curbing of the outdoor challenges faced by wood products in service.

\section{MATERIALS AND METHODS}

Three fairly straight, 40-year old defect-free B. aethiopum cylindrical trunks each from the two varieties were randomly harvested $50 \mathrm{~cm}$ above the ground level from Kobreso, a dry semi-deciduous forest zone in the Offinso North Forest District of the Ashanti Province, Ghana. Cross-sectional were sawn from the peripheries (i.e., the dermal zones) and cores (i.e., the sub-dermal zones) from the base position $(2,4 \mathrm{~m})$, middle $(10,6 \mathrm{~m})$ 
and crown $(18,8 \mathrm{~m})$ sections of each variety. Each was wrapped immediately with aluminium foil and kept in air-tight plastic bags to prevent any moisture loss or gain. They were used to determine some selected physical properties.

\section{Physical properties of B. aethiopum}

\section{Moisture content}

The MC was determined from $10(20 \mathrm{~mm} \times 20 \mathrm{~mm} \times 20 \mathrm{~mm})$ each from the peripheries (at the depth of $70 \mathrm{~mm}$ ) and the cores ( $150 \mathrm{~mm}$ from the periphery) of the base, middle, and crown. Ten replicates of the sawn from each portion were oven-dried at $103^{\circ} \mathrm{C} \pm 2{ }^{\circ} \mathrm{C}$ to their constant weights. They were cooled in a desiccator and their MCs determined according to Panshin and de Zeeuw 1980 (Equation 1).

$$
M C(\%)=\frac{W_{1}-W_{0}}{W_{0}} \times 100
$$

Where: $\mathrm{MC}=$ Moisture Content; $\mathrm{W}_{1}=$ Initial weight of wood sample $(\mathrm{g}) ; \mathrm{W}_{0}=$ Oven-dry weight of the sample (g).

\section{Basic density}

The basic density at the green and dry states for each sample (20 $\mathrm{mm}$ x $20 \mathrm{~mm} \times 20 \mathrm{~mm})$ was determined at the constant oven-dry weight (at $103^{\circ} \mathrm{C} \pm 2{ }^{\circ} \mathrm{C}$ ) and volume as follows (Equation 2):

$$
D_{o}=\frac{M_{0}}{V_{0}} x 100
$$

Where: $\mathrm{D}_{0}=$ Density of the sample $\left(\mathrm{g} / \mathrm{mm}^{3}\right) ; \mathrm{M}_{0}=$ Oven-dried weight of the sample $(\mathrm{g}) ; \mathrm{V}_{0}=$ Volume (length, width, thickness) of the sample $\left(\mathrm{mm}^{3}\right)$.

\section{Dimensional stability}

\section{Swelling}

Measuring $152 \mathrm{~mm}$ (Longitudinal), $76 \mathrm{~mm}$ (Tangential), and $5 \mathrm{~mm}$ (Radial), based on ASTM D1037-06a (2006) were taken from the axial and radial portions of each variety. Their radial, tangential and longitudinal swellings were calculated separately from the formula of Kollmann and Côte 1984 (Equation 3).

$$
\text { Swelling }=\frac{W d a-W d b}{W d a} \times 100
$$

Where: $\mathrm{Wda}=$ Wood dimension after immersion; $\mathrm{Wdb}=$ Wood dimension before immersion.

The volumetric swelling for each was determined from the values for their radial, tangential, and longitudinal faces (Mantanis et al. 1994) as the following Equation (4).

$$
\text { Volumetric Swelling }(\%)=\frac{\text { Sl } x \text { St } x S r-D l \times D t \times D r}{D l \times D t \times D r} \times 100
$$

Where: $\mathrm{Sl}=$ Longitudinal dimension of the in swollen condition; $\mathrm{St}=$ Tangential dimension of in swollen 
condition; $\mathrm{Sr}=$ Radial dimension of in swollen condition; $\mathrm{Dl}=$ Longitudinal dimension of in dry condition; $\mathrm{Dt}$ $=$ Tangential dimension of in dry condition; $\mathrm{Dr}=$ Radial dimension of in dry condition .

\section{Shrinkage}

The radial, tangential, longitudinal, and volumetric shrinkages for the (20 $\mathrm{mm} \times 20 \mathrm{~mm} \times 20 \mathrm{~mm})$ from the axial and radial stem positions were determined from the two varieties. The formulae for calculating the shrinkages were based on the Panshin and de Zeeuw 1980 assessment as (Equation 5, Equation 6, Equation 7):

$$
\begin{aligned}
& \beta R=\frac{R S-R o}{R S} \times 100 \text { (Radial direction) } \\
& \beta T=\frac{T S-T o}{T S} \times 100 \text { (Tangential direction) } \\
& \beta L=\frac{L S-L o}{L S} \times 100 \text { (Longitudinal direction) }
\end{aligned}
$$

Thereafter, the volumetric shrinkage for each was calculated based on Mantanis et al. 1994, Boadu et al. 2017 as (Equation 8).

$$
\beta V=\frac{\operatorname{Ls} x \operatorname{Ts} x R s-\operatorname{Lox} \operatorname{Tox} R o}{\operatorname{Ls} x \operatorname{Ts} x \operatorname{Rs}} \times 100
$$

Where: $\beta \mathrm{L}=$ Longitudinal shrinkage of the specimen; $\beta \mathrm{T}=$ Tangential shrinkage; $\beta \mathrm{R}=$ Radial shrinkage; $\beta \mathrm{v}=$ Volume shrinkage; Ls $=$ Longitudinal dimension of the saturated specimen; Rs $=$ Radial dimension of the saturated specimen; Ts = Tangential dimension of the saturated specimen; Lo $=$ Longitudinal dimension of the dried specimen; Ro = Radial dimension of the dried specimen; To = Tangential dimension of the dried specimen.

\section{RESULTS AND DISCUSSION}

\section{Physical properties of B. aethiopum}

\section{Moisture content}

The male had the lowest green MC (59,03\%) at the periphery of the base but it recorded the greatest (89, $62 \%)$ at its crown. The core of the base had the lowest MC (61,31\%) but greatest $(129,42 \%)$ at its crown. The identical trend was recorded for the female variety. The lowest $(56,38 \%)$ was at the periphery of the base, and the greatest $(85,90 \%)$ at the periphery of the core. Similarly, the core of the base recorded less $(71,96 \%)$ than the core of the crown (137,98 \%). Thus, the two varieties had increased MC upwards from the periphery of the base to the core of the crown at a range of 59,03\% - 129,42\% for the male and 56,38 \% - 137,98\% for the female (Table 1). Moreover, the male recorded less mean green MC $(77,63 \%)$ and more at the dry state $(12,49 \%)$ than the female at green state: $81,49 \%$; dry state: $12,44 \%$ within the boles. Both varieties had a consistent increasing trend from the peripheries to the cores along the bole at the base, middle, and crown MC significantly affects the anisotropic properties and field performance of wood and its utilization in service. The amount does not only influence wood strength, stiffness, and mode of failure but also its dimensions, susceptibility to fungal and other biodegradation, workability, and ability to accept adhesives and finishes. Among the palms, the studied MC trend for the two varieties of B. aethiopum (especially at the crowns) had less MC compares with that for the Elaeis guineesis trunk (100\% - $500 \%)$ reported by Killman and Choon (1985) and $258 \%-575,5 \%$ by Bakar et al. (1998). Asafu-Adjaye (2011) recorded between 49,70\% and 71,70\% MC for $B$. aethiopum from different growth site and confirmed a gradual increase along with the trunk height and towards the central region. In all, the peripheral/dermal zones had a far less MC than their cores (from the base 
to the crown). A similar trend was identified by Lim and Khoo (1986) for Elaeis guineesis at its peripheral zone $(120 \%-194 \%)$ with a mean of $151 \%$, inner zone (332\% - 532\%) with a mean of $434 \%$, central zone (303\% - $435 \%$ ) with a mean of $379 \%$. The less MC within the two varieties of B. aethiopum compares with those of Phoenix dactilifera and Cocos nucifera palms, which all recorded a mean of $50 \%$ at the bottom outer portions to $400 \%$ at the top portions of the stem core (Fathi 2014) are indicative of B. aethiopum potential suitability for structural applications. Nevertheless, those for timber species are generally lower than for B. aethiopum. For instance, Effah (2012) recorded 44,32 \% - 115,22 \% for Cola nitida with a mean of $66,61 \%$ but $60,50 \%$ to 99,44 \% (Mean: 79,41 \%) for Funtumia elasstica, while Antwi (2012) recorded 43,90 \% to 100,70 \% (Mean: $81,19 \%$ ) for Allanblackia parviflora. In all, MC increased upwards within the trees.

Moisture relationship has an important influence on wood and its product properties, quality, and service-live performance (Erwinsyah 2008). MC also has negative implications on the dimensional movement of wood. Wood products, which easily absorb excessive moisture are rapidly affected by biological infestations, as moisture attracts biological agents such as insects and microbes that lead to wood mass loss and less durability (Kirk and Culen 1998). The core portions recorded greater MC and are likely prone to swelling and shrinkage more than the periphery, which could have negative implications on the products made from the sub-dermal zones, as they would be more susceptible to moisture fluctuations and biodegradation. Moreover, the cores would not be useful exteriorly but suitable for indoor applications including ceiling, manufacturing of furniture, and interior decorations for buildings and vehicles. MC can also swell wood products from the core and cause artificial defects such as warping, cupping, honey-combing, weathering, strength loss, and reduction in caloric value.

\section{Density}

The green and dry densities recorded a consistent decreasing trend up the bole with better peripheries than the cores for both varieties. At the radial positions, the peripheries had $960,5 \mathrm{~kg} / \mathrm{m}^{3}-496 \mathrm{~kg} / \mathrm{m}^{3}$ and $1026,5 \mathrm{~kg} /$ $\mathrm{m}^{3}-525 \mathrm{~kg} / \mathrm{m}^{3}$ for the male and female respectively at green state and $827 \mathrm{~kg} / \mathrm{m}^{3}-315,5 \mathrm{~kg} / \mathrm{m}^{3}$ and $754,5 \mathrm{~kg} /$ $\mathrm{m}^{3}-280,5 \mathrm{~kg} / \mathrm{m}^{3}$ respectively at the dry state. The core, nearer the pith, also recorded $783-450 \mathrm{~kg} / \mathrm{m}^{3}$ and 666 $\mathrm{kg} / \mathrm{m}^{3}-422,5 \mathrm{~kg} / \mathrm{m}^{3}$ for male and female at the green state but $451,5 \mathrm{~kg} / \mathrm{m}^{3}-264 \mathrm{~kg} / \mathrm{m}^{3}$ and $424,5 \mathrm{~kg} / \mathrm{m}^{3}-219,5$ $\mathrm{kg} / \mathrm{m}^{3}$ respectively at the dry state. Axially, densities decreased from the base of the male $\left(960,5 \mathrm{~kg} / \mathrm{m}^{3}\right)$ to the crown $\left(450 \mathrm{~kg} / \mathrm{m}^{3}\right)$; similar to the female $\left(1026,5 \mathrm{~kg} / \mathrm{m}^{3}\right.$ (at base) $-422,5 \mathrm{~kg} / \mathrm{m}^{3}$ (crown)) at the green state. At the dry state, the male had $827 \mathrm{~kg} / \mathrm{m}^{3}$ at its base and $264 \mathrm{~kg} / \mathrm{m}^{3}$ at the crown, while the female recorded 754,5 $\mathrm{kg} / \mathrm{m}^{3}$ at the base and $219,5 \mathrm{~kg} / \mathrm{m}^{3}$ at its crown. Generally, the male recorded a mean density of $723,08 \mathrm{~kg} / \mathrm{m}^{3}$ and $508,58 \mathrm{~kg} / \mathrm{m}^{3}$ at the green and dry states respectively, while the female similarly had $640,92 \mathrm{~kg} / \mathrm{m}^{3}$ and $404,92 \mathrm{~kg} / \mathrm{m}^{3}$ (Table 1). Findings from the study depicted in Figure 1 confirms the variabilities of MC and density along the boles in the green and dry states.

Some timbers exhibit greater variation in density than others. Wood density is an important property that affects the performance of timber and usually decrease from the base to the crown (Belleville et al. 2020) and from the heartwood to the sapwood on one hand and also from the periphery of the base to the core of the crown for the palms (Bakar et al. 1998, Kimberley et al. 2017). The peripheries from both varieties recorded greater densities at the green and dry states than the cores along the bole (Table 1). This indicates the commercial acceptance of the peripheral portions for structural applications than the cores. Ayarkwa (1997) recorded $670 \mathrm{~kg} / \mathrm{m}^{3}$ for B. aethiopum, while Asafu-Adjaye (2011) had 793,3 kg/m $3 \mathrm{~m}^{3}-579,1 \mathrm{~kg} / \mathrm{m}^{3}$, and approximately $700 \mathrm{~kg} / \mathrm{m}^{3}-1065 \mathrm{~kg} / \mathrm{m}^{3}$ (Li et al. 2018). Similarly, they observed a consistent decrease in trend up the bole for the periphery and the core. Several studies on Elaeis guineesis, Cocos nucifera and Phoenix dactilifera palms by Lim and Khoo (1986), Prayitno (1995), Romulo and Arancon (1997), Bakar et al. (1998), Erwinsyah (2008) and Fathi (2014) proved identical trends where densities gradually decreased from the peripheral portions to the cores and from the base through the middle to the crown at a range of $100 \mathrm{~kg} / \mathrm{m}^{3}$ to $900 \mathrm{~kg} / \mathrm{m}^{3}$.

The patterns for the densities of these palms are, once again, in contrast with those for wood species, which have an increase in density from the outer sapwood to the inner heartwood (Karlman et al. 2005). The authors recorded a mean density of $506 \mathrm{~kg} / \mathrm{m}^{3}$ (range: $475 \mathrm{~kg} / \mathrm{m}^{3}-555 \mathrm{~kg} / \mathrm{m}^{3}$ ) for Scots pine (Pinus sylvestris L.) and $618 \mathrm{~kg} / \mathrm{m}^{3}$ (range: $535 \mathrm{~kg} / \mathrm{m}^{3}-670 \mathrm{~kg} / \mathrm{m}^{3}$ ) for larch trees, while Akpan et al. (1999) recorded $256 \mathrm{~kg} / \mathrm{m}^{3}-894$ $\mathrm{kg} / \mathrm{m}^{3}$ for B. guianensis. As an essential quality and determining factor of wood, density has been strongly associated with strength, stiffness, hardness, durability, and other properties, which influence wood commercial utilization. The heavier peripheral portions with corresponding great strength properties would make them more viable candidates for exterior and structural applications than the cores and even several other timbers like Parinari excelsa Sabine (afam) whose wood density ranges $530 \mathrm{~kg} / \mathrm{m}^{3}-730 \mathrm{~kg} / \mathrm{m}^{3}$ at $12 \% \mathrm{MC}$ or 900 $\mathrm{kg} / \mathrm{m}^{3}$ at $12 \%-15 \% \mathrm{MC}$ ), hard and strong for tough exterior use as heavy-duty structures, industrial floors, 
mining, vehicle, and boat construction.

FAO (1985) and TEDB (1994) reported that at $12 \% \mathrm{MC}$, wood density should be graded as High (i.e., Very heavy), Medium, and Low with these values: $>500 \mathrm{~kg} / \mathrm{m}^{3} ; 350 \mathrm{~kg} / \mathrm{m}^{3}-500 \mathrm{~kg} / \mathrm{m}^{3} ;<350 \mathrm{~kg} / \mathrm{m}^{3} \mathrm{respec}-$ tively. Thus, the densities for the peripheries of the male $B$. aethiopum at the base $\left(827 \mathrm{~kg} / \mathrm{m}^{3}\right)$ and middle $\left(746,5 \mathrm{~kg} / \mathrm{m}^{3}\right)$ and that of the female $\left(754,5 \mathrm{~kg} / \mathrm{m}^{3}\right.$ and $506 \mathrm{~kg} / \mathrm{m}^{3}$ respectively) would be graded as Very heavy. The core at the base $\left(451,5 \mathrm{~kg} / \mathrm{m}^{3}\right)$ and middle $\left(447 \mathrm{~kg} / \mathrm{m}^{3}\right)$ of the male, and that of the base from the female $\left(424,5 \mathrm{~kg} / \mathrm{m}^{3}\right)$ would be classified as Medium density. The periphery $\left(315,5 \mathrm{~kg} / \mathrm{m}^{3}\right)$ and core at the crown $(260$ $\left.\mathrm{kg} / \mathrm{m}^{3}\right)$ of the male, as well as the periphery of the crown $\left(280,5 \mathrm{~kg} / \mathrm{m}^{3}\right)$, the core of the middle $\left(244,5 \mathrm{~kg} / \mathrm{m}^{3}\right)$ and crown $\left(219,5 \mathrm{~kg} / \mathrm{m}^{3}\right)$ of the female (Table 1), would be graded as low density. Generally, the peripheries and cores of the two varieties recorded a consistent decreasing trend up the crown at both green and dry states, while the bole decreased in density radially from the dermal zone to the pith. The portions with the greatest densities could possess excessive total extractives and lignin that can render them less swelling and shrinkage characteristics and would be suitable for structural works including flooring, bridges, roofing, paneling, and exterior furniture. The medium density portions would be useful for stools, chairs, windows, doors, the interior of cars, while the low-density portions would be useful for stakes for agricultural purposes, pencils, walking sticks, the cork of bottles, packaging, and other interior product designs.

Table 1: Moisture content and density variabilities within the two Borassus aethiopum.

\begin{tabular}{|c|c|c|c|c|c|c|}
\hline \multirow[t]{2}{*}{ Varieties } & \multicolumn{2}{|c|}{ Stem positions } & \multicolumn{4}{|c|}{ Physical Properties } \\
\hline & Radial & Axial & $\begin{array}{c}\text { Green MC } \\
(\%)\end{array}$ & $\begin{array}{c}\text { Dry MC } \\
(\%)\end{array}$ & $\begin{array}{l}\text { Green Density } \\
\left(\mathrm{kg} / \mathrm{m}^{3}\right)\end{array}$ & $\begin{array}{l}\text { Dry Density } \\
\left(\mathrm{kg} / \mathrm{m}^{3}\right)\end{array}$ \\
\hline \multirow{7}{*}{ Male } & \multirow{3}{*}{$\begin{array}{l}\text { Periphery } \\
\text { (Dermal) }\end{array}$} & Base & $59,03^{\mathrm{d}}(0,58)$ & $12,19^{\mathrm{d}}(0,13)$ & $960,5^{\mathrm{a}}(31,57)$ & $827^{\mathrm{a}}(53,40)$ \\
\hline & & Middle & $60,14^{\mathrm{d}}(1,63)$ & $12,33^{\text {cd }}(0,28)$ & $912^{\mathrm{a}}(129,17)$ & $746,5^{\mathrm{c}}(94,69)$ \\
\hline & & Crown & $89,62^{\mathrm{b}}(4,27)$ & $12,52^{\mathrm{bc}}(0,23)$ & $496^{\mathrm{c}}(39,92)$ & $315,5^{\mathrm{d}}(64,34)$ \\
\hline & \multirow{3}{*}{$\begin{array}{l}\text { Core (sub- } \\
\text { dermal) }\end{array}$} & Base & $61,31^{\mathrm{d}}(3,42)$ & $12,35^{\mathrm{cd}}(0,14)$ & $783^{b}(75,76)$ & $451,5^{\mathrm{c}}(33,00)$ \\
\hline & & Middle & $66,28^{\mathrm{c}}(2,2)$ & $12,65^{\mathrm{ab}}(0,17)$ & $737^{b}(65,58)$ & $447^{\mathrm{c}}(51,11)$ \\
\hline & & Crown & $129,42^{\mathrm{e}}(6,63)$ & $12,94^{\mathrm{a}}(0,7)$ & $450^{\mathrm{c}}(36,21)$ & $264^{\mathrm{e}}(16,13)$ \\
\hline & Means & & 77,63 & 12,49 & 723,08 & 508,58 \\
\hline \multirow{6}{*}{ Female } & \multirow{3}{*}{$\begin{array}{l}\text { Periphery } \\
\text { (Dermal) }\end{array}$} & Base & $56,38^{\mathrm{D}}(4,1)$ & $12,29^{C}(0,12)$ & $1026,5^{A}(177,11)$ & $754,5^{A}(102,81)$ \\
\hline & & Middle & $6226^{\mathrm{D}}(9,72)$ & $12,36^{\mathrm{BC}}(0,17)$ & $724,5^{\mathrm{B}}(27,93)$ & $506^{\mathrm{B}}(51,14)$ \\
\hline & & Crown & $85,9^{\mathrm{B}}(5,47)$ & $12,51^{\mathrm{AB}}(0,09)$ & $525^{\mathrm{C}}(49,33)$ & $280,5^{\mathrm{D}}(41,46)$ \\
\hline & \multirow{3}{*}{$\begin{array}{l}\text { Core (Sub- } \\
\text { dermal) }\end{array}$} & Base & $71,96^{\mathrm{C}}(11,79)$ & $12,43^{\mathrm{BC}}(0,13)$ & $666^{\mathrm{B}}(48,58)$ & $424,5^{\mathrm{C}}(33,54)$ \\
\hline & & Middle & $74,47^{\mathrm{C}}(13,11)$ & $12,51^{\mathrm{A}}(0,17)$ & $481^{\mathrm{CD}}(44,59)$ & $244,5^{\mathrm{DE}}(32,61)$ \\
\hline & & Crown & $\begin{array}{c}137,98^{A}(7,7) \\
81,49\end{array}$ & $\begin{array}{c}12,53^{\mathrm{A}}(0,29) \\
12,44\end{array}$ & $\begin{array}{c}422,5^{\mathrm{D}}(30,39) \\
640,92\end{array}$ & $\begin{array}{c}219,5^{\mathrm{E}}(14,99) \\
404,92\end{array}$ \\
\hline
\end{tabular}

Values in the same column with the same letter are not significantly different $(\mathrm{P}<0,05)$. 

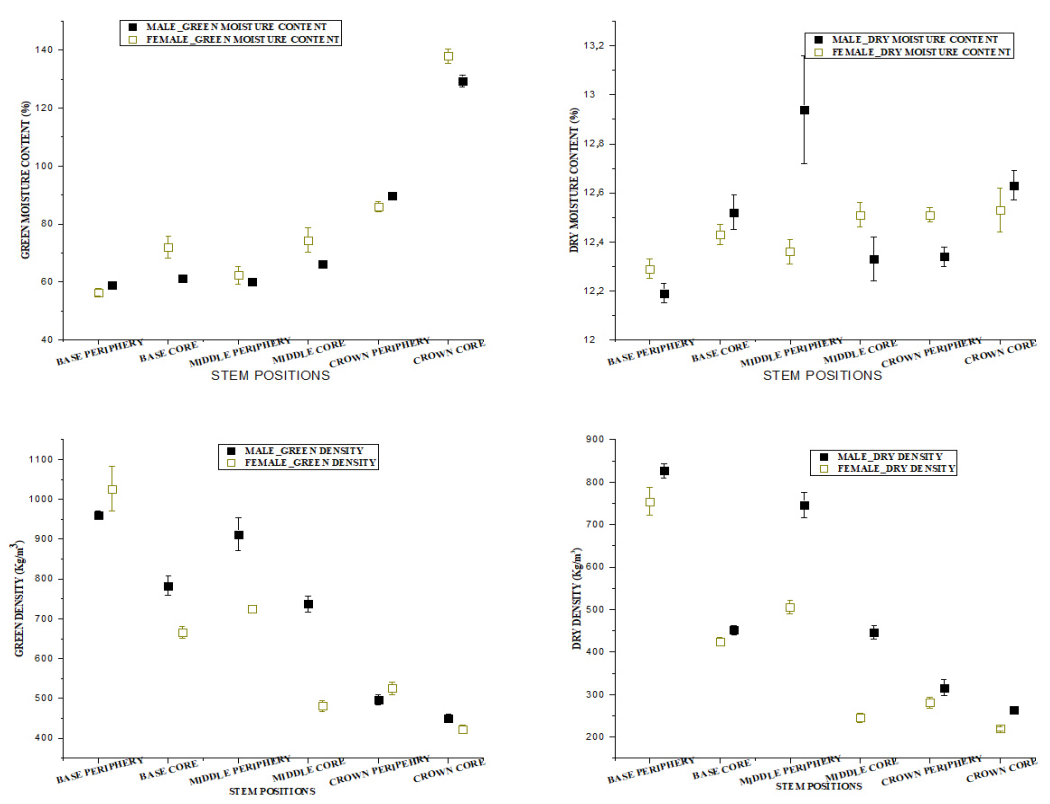

Figure 1: MC and density variabilities within the two Borassus aethiopum.

\section{Dimensional stability}

\section{Swelling}

Generally, the radial, longitudinal, and tangential swellings of the two varieties showed inconsistent variations (Table 2). The longitudinal swelling at the periphery decreased as: middle $(0,25 \%)>$ base $(0,24 \%)$ $>$ crown $(0,22 \%)$. However, the base and the crown at the core swelled more $(0,36 \%)$ than the middle $(0,29$ $\%)$. The tangential swelling for the periphery ranked in this decreasing order: base $(1,68 \%)>$ middle $(1,08 \%)$ $>$ crown $(0,62 \%)$. However, its core had inconsistent pattern: crown $(2,24 \%)>$ base $(1,60 \%)>$ middle $(1,07$ $\%)$. Radially, the swelling also decreased inconsistently within the periphery: middle $(3,37 \%)>$ crown $(3,05$ $\%)>$ base $(2,55 \%)$, and in the core: base $(4,76 \%)>$ crown $(3,69 \%)>$ middle $(2,84 \%)$. For the female, the trends for swelling were also inconsistent except at the longitudinal direction for the core (crown $>$ middle $>$ base: $0,52 \%, 0,28 \%$, and $0,22 \%$ respectively). Volumetric swelling showed no regular trend for the periphery of the male unlike the core that decreased from the base $(6,99 \%)$ to the middle $(4,15 \%)$ and crown $(4,14 \%)$. Volumetric swelling was similarly inconsistent for the periphery and core for the female. Mostly, the cores swelled much (i.e., 6,99\% and 6,23\% for the male and female respectively) than their peripheries (male: $4,76 \%$ and female: $4,75 \%$ ). Nonetheless, the female swelled much more than the male (Table 2). The study depicted in Figure 2 confirms the swelling characteristics along the boles of both Borassus aethiopum.

Swelling of wood is of fundamental significance in the context of commercial applications of timber. Wood mostly swell less in the longitudinal surface $(0,1-0,4 \%)$ than in the tangential $(3 \%-6 \%)$ and radial directions (6\% - $12 \%$ ) (Gryc and Horácek 2007). Akpan et al. (1999), in a study, reported that B. guianensis wood swells less along the longitudinal direction $(1 \%-1,33 \%)$ than the tangential and radial directions $(11,32$ $\%-14,08 \%$ and 5,29 \% - 7,01 \% respectively). The study shown in Table 2 confirms the reports by cited authors. The male B. aethiopum recorded less directional swelling at its periphery for the longitudinal, tangential, radial, and the volumetric swelling than those from the cores. A similar trend was identified at the periphery of the female. Thus, the peripheries from both varieties recorded less swelling than the cores up the entire bole. Besides their efficient swelling stability, the peripheral regions' less MC and great density would contribute to making them more resistant to biodegradation, weathering, and add value to the wood quality than the cores. These can make the peripheries more structural useful for external applications than the core portions. 


\section{Shrinkage}

Along the male bole, shrinkage increased consistently from the peripheral base to the crown at the longitudinal direction (base: 1,11 \%, middle: $1,91 \%$ and crown: $2,79 \%)$ and at the radial surface: base $(2,42$ $\%)<$ middle $(2,84 \%)<$ crown $(3,04 \%)$. Moreover, the longitudinal shrinkage had inconsistent trend at the female periphery: base $(1,32 \%)<$ crown $(2,68 \%)<$ middle $(2,86 \%)$, and also at the core: middle $<$ base $<$ crown (i.e., $2,94 \%<3,48 \%<3,94 \%$ respectively). Tangentially, shrinkage was $2,24 \%, 3,14 \%$ and 2,23\% for the base, middle and crown respectively at the periphery but consistently increased within the core from the base $(2,48 \%)$, middle $(2,70 \%)$ to the crown $(2,76 \%)$. Radial shrinkage exhibited an inconsistent pattern, particularly at the core: middle $(3,41 \%)<$ base $(3,16 \%)<$ crown $(2,53 \%)$. Generally, there was a consistent increasing trend for volumetric shrinkage for the periphery (i.e., 5,88 \%<9,43\%<9,93\% at the base, middle and crown respectively) unlike at the core: middle $(8,17 \%)$, base $(8,63 \%)$ and crown $(10,69 \%)$ for the male. The volumetric shrinkage for the female recorded inconsistent pattern both at the periphery and the core (Table 2). Findings from the study display in Figure 3 confirms shrinkage characteristics along the boles of both Borassus aethiopum.

Table 2: Swelling variabilities within the two Borassus aethiopum.

\begin{tabular}{|c|c|c|c|c|c|c|}
\hline \multirow[t]{2}{*}{ Varieties } & \multicolumn{2}{|c|}{ Stem positions } & \multicolumn{4}{|c|}{ Dimensional Stability } \\
\hline & Radial & Axial & $\begin{array}{c}\text { Radial Swelling } \\
(\%)\end{array}$ & $\begin{array}{l}\text { Longitudinal } \\
\text { Swelling }(\%)\end{array}$ & $\begin{array}{c}\text { Tangential } \\
\text { Swelling (\%) }\end{array}$ & $\begin{array}{c}\text { Volumetric } \\
\text { Swelling (\%) }\end{array}$ \\
\hline \multirow{6}{*}{ Male } & \multirow{3}{*}{$\begin{array}{l}\text { Periphery } \\
\text { (Dermal) }\end{array}$} & Base & $2,55^{\mathrm{c}}(0,85)$ & $0,24^{\mathrm{a}}(0,13)$ & $1,68^{\mathrm{ab}}(0,94)$ & $4,76^{b}(1,05)$ \\
\hline & & Middle & $3,37^{\mathrm{bc}}(0,89)$ & $0,25^{\mathrm{a}}(0,13)$ & $1,08^{\mathrm{bc}}(0,61)$ & $2,89^{\mathrm{c}}(0,79)$ \\
\hline & & Crown & $3,05^{\mathrm{bc}}(1,1)$ & $0,22^{\mathrm{a}}(0,13)$ & $0,63^{\mathrm{c}}(0,34)$ & $3,83^{\mathrm{bc}}(1,26)$ \\
\hline & \multirow{3}{*}{$\begin{array}{l}\text { Core (sub- } \\
\text { dermal) }\end{array}$} & Base & $4,76^{\mathrm{a}}(1,23)$ & $0,36^{\mathrm{a}}(0,17)$ & $1,6^{\mathrm{b}}(0,64)$ & $6,99^{\mathrm{a}}(1,23)$ \\
\hline & & Middle & $2,84^{\mathrm{bc}}(0,83)$ & $0,29^{\mathrm{a}}(0,1)$ & $1,07^{\mathrm{bc}}(0,25)$ & $4,15^{b}(0,57)$ \\
\hline & & Crown & $3,69^{6}(1,48)$ & $0,36^{\mathrm{a}}(0,16)$ & $2,24^{\mathrm{a}}(1,06)$ & $4,14^{b}(1,79)$ \\
\hline \multirow{6}{*}{ Female } & \multirow{3}{*}{$\begin{array}{l}\text { Periphery } \\
\text { (Dermal) }\end{array}$} & Base & $2,14^{\mathrm{C}}(0,56)$ & $0,31^{\mathrm{BC}}(0,05)$ & $1,65^{\mathrm{AB}}(0,5)$ & $4,51^{\mathrm{AB}}(0,66)$ \\
\hline & & Middle & $2,97^{\mathrm{B}}(1,03)$ & $0,22^{\mathrm{C}}(0,14)$ & $1,39^{\mathrm{B}}(0,79)$ & $4,75^{\mathrm{B}}(1,48)$ \\
\hline & & Crown & $2,38^{\mathrm{BC}}(0,71)$ & $0,48^{\mathrm{BC}}(0,28)$ & $0,69^{C}(0,62)$ & $4,01^{\mathrm{B}}(1,64)$ \\
\hline & \multirow{3}{*}{$\begin{array}{l}\text { Core (Sub- } \\
\text { dermal) }\end{array}$} & Base & $2,59^{\mathrm{BC}}(0,5)$ & $0,22^{C}(0,14)$ & $2,21^{\mathrm{A}}(0,59)$ & $5,22^{\mathrm{AB}}(0,59)$ \\
\hline & & Middle & $4,66^{A}(1,14)$ & $0,28^{C}(0,11)$ & $1,15^{\mathrm{BC}}(0,43)$ & $6,23^{A}(2,1)$ \\
\hline & & Crown & $2,69^{C}(0,52)$ & $0,52^{A}(0,34)$ & $1,72^{\mathrm{AB}}(0,88)$ & $4,79^{\mathrm{B}}(1,22)$ \\
\hline
\end{tabular}

Values in the same column with the same letter are not significantly different $(\mathrm{P}<0,05)$. 

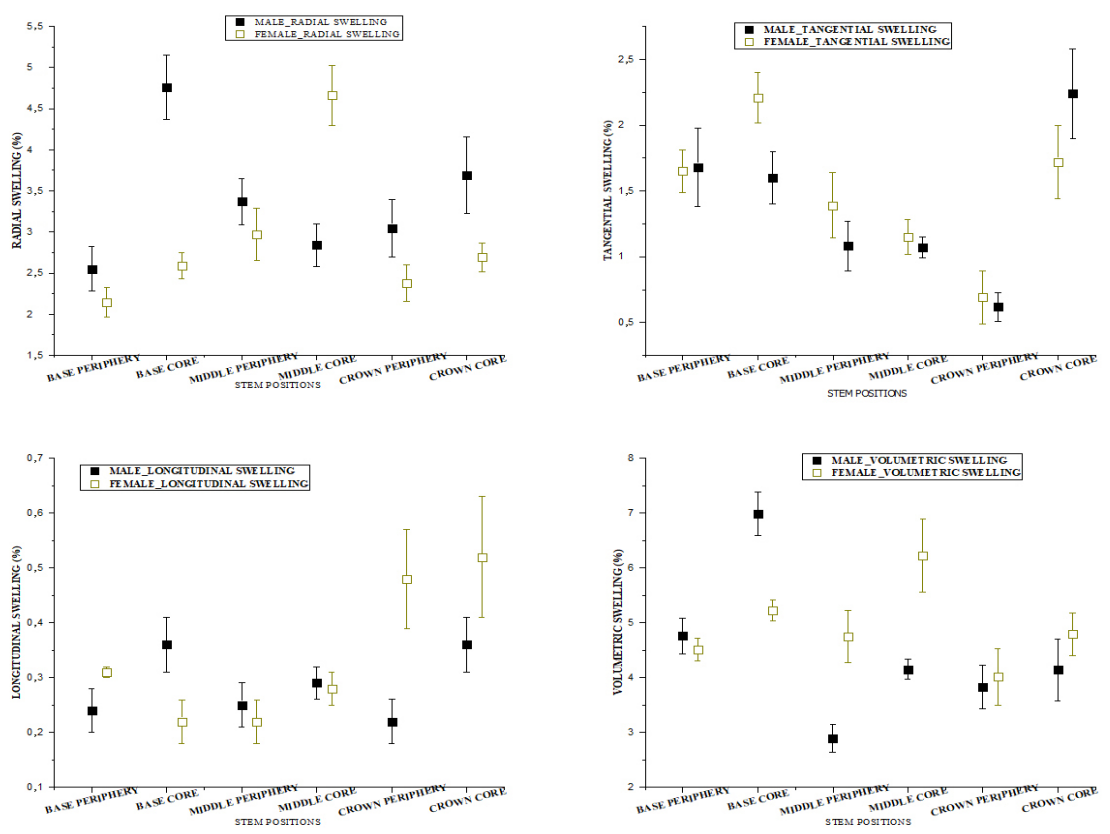

Figure 2: Swelling variabilities within the two Borassus aethiopum.

Shrinkage usually increases from the base of a tree to the crown or from the inner (heart) wood to outer (sap) wood of most timber species (Shupe et al. 1995). However, among palms, Erwinsyah (2008) noted that shrinkage in Elaeis guineesis trunks was greater in the central zones $(19,6 \%)$ at a range of $13-23 \%$ than in the inner and peripheries, which had a mean of 16,7\% (a range of $11 \%-20 \%$ ) and 16,8 \% (range: $10 \%$ $23 \%$ respectively. That is, the spongy portions shrunk more than its stiffer areas. Koubaa et al. (1998) and Fathi (2014) confirmed that shrinkage increased in both tangential and radial directions but not significantly at the longitudinal direction, as in silka spruce and Bagassa guianensis Aubl (Bossu et al. 2016). The male B. aethiopum of the study recorded similar trends with the cores having greater longitudinal, tangential and radial shrinkages than at the peripheries. The longitudinal and radial shrinkages followed the identical pattern with the cores recording greater values $(3,69 \%$ for longitudinal and 3,54 \% for radial) than their peripheries $(1,11$ $\%$ and $2,42 \%$ respectively) unlike tangential shrinkage, which had 2,83\% for the periphery and 2,64 \% for the core. Volumetrically, the male shrunk much at the cores $(9,16 \%$, ranging from $8,17 \%-10,68 \%)$, while its peripheries recorded $8,41 \%$ (range: $5,88 \%-9,93 \%$ ). The female also recorded greater mean at the cores $(9,07 \%$; range $=9,08 \%-9,22 \%)$ than the peripheries $(7,41 \%$; range $=6,82 \%-8,40 \%)$. The dermal zones of the two varieties shrank far less at all the three surfaces and volumetrically than those at the cores. This could be ascribed to the lower MC, less swelling but greater densities along the peripheries than at the cores. Thus, the peripheries along the bole can have better dimensional stabilities making them less likely to warp, bow, crack, split, swell excessively and be more resistant to biological degradation, which makes them functional for structural and industrial applications than their cores. 
Table 3: Shrinkage variabilities within the two Borassus aethiopum.

\begin{tabular}{|c|c|c|c|c|c|c|}
\hline \multirow{2}{*}{ Varieties } & \multicolumn{2}{|c|}{ Stem positions } & \multicolumn{4}{|c|}{ Dimensional Stability } \\
\hline & Radial & Axial & $\begin{array}{c}\text { Radial Shrinkage } \\
\text { (\%) }\end{array}$ & $\begin{array}{c}\text { Longitudinal } \\
\text { Shrinkage } \\
(\%)\end{array}$ & $\begin{array}{c}\text { Tangential } \\
\text { Shrinkage } \\
(\%)\end{array}$ & $\begin{array}{c}\text { Volumetric } \\
\text { Shrinkage } \\
(\%)\end{array}$ \\
\hline \multirow{6}{*}{ Male } & \multirow{3}{*}{$\begin{array}{l}\text { Periphery } \\
\text { (Dermal) }\end{array}$} & Base & $2,42^{b}(0,49)$ & $1,11^{\mathrm{c}}(0,30)$ & $1,76^{\mathrm{c}}(0,54)$ & $5,88^{d}(0,66)$ \\
\hline & & Middle & $2,84^{b}(1,21)$ & $1,91^{\mathrm{bc}}(0,72)$ & $3,50^{\mathrm{ab}}(1,07)$ & $9,43^{b}(1,18)$ \\
\hline & & Crown & $3,04^{\mathrm{ab}}(0,75)$ & $2,79^{\mathrm{ab}}(0,37)$ & $3,32^{\mathrm{ab}}(0,40)$ & $9,93^{\mathrm{ab}}(0,00)$ \\
\hline & \multirow{3}{*}{$\begin{array}{l}\text { Core (sub- } \\
\text { dermal) }\end{array}$} & Base & $3,01^{\mathrm{ab}}(0,88)$ & $2,32^{b}(0,57)$ & $3,57^{\mathrm{ab}}(0,30)$ & $8,63^{\mathrm{b}}(0,79)$ \\
\hline & & Middle & $3,54^{\mathrm{a}}(1,17)$ & $3,69^{a}(2,24)$ & $2,93^{\mathrm{c}}(0,31)$ & $8,17^{\mathrm{a}}(0,00)$ \\
\hline & & Crown & $3,42^{a}(0,71)$ & $3,35^{\mathrm{a}}(0,07)$ & $4,04^{\mathrm{a}}(1,13)$ & $10,69^{\mathrm{a}}(1,18)$ \\
\hline \multirow{6}{*}{ Female } & \multirow{3}{*}{$\begin{array}{l}\text { Periphery } \\
\text { (Dermal) }\end{array}$} & Base & $3,27^{\mathrm{A}}(081)$ & $1,32^{\mathrm{C}}(0,84)$ & $2,24^{\mathrm{B}}(0,63)$ & $6,82^{\mathrm{C}}(1,06)$ \\
\hline & & Middle & $2,76^{\mathrm{AB}}(0,58)$ & $2,86^{\mathrm{AB}}(1,10)$ & $3,14^{\mathrm{A}}(0,91)$ & $8,40^{\mathrm{AB}}(1,52)$ \\
\hline & & Crown & $2,35^{\mathrm{C}}(0,51)$ & $2,68^{\mathrm{B}}(1,23)$ & $2,23^{\mathrm{B}}(0,66)$ & $7,01^{\mathrm{BC}}(1,68)$ \\
\hline & \multirow{3}{*}{$\begin{array}{l}\text { Core (Sub- } \\
\text { dermal) }\end{array}$} & Base & $3,16^{\mathrm{AB}}(0,74)$ & $3,48^{\mathrm{AB}}(1,17)$ & $2,48^{\mathrm{AB}}(1,00)$ & $9,08^{\mathrm{A}}(1,49)$ \\
\hline & & Middle & $3,41^{A}(1,38)$ & $2,94^{\mathrm{AB}}(1,32)$ & $2,70^{\mathrm{B}}(1,22)$ & $8,92^{\mathrm{A}}(1,83)$ \\
\hline & & Crown & $2,53^{\mathrm{BC}}(0,32)$ & $3,94^{\mathrm{A}}(1,66)$ & $2,76^{\mathrm{AB}}(0,50)$ & $9,22^{\mathrm{A}}(1,82)$ \\
\hline
\end{tabular}

Values in the same column with the same letter are not significantly different $(\mathrm{P}<0,05)$.
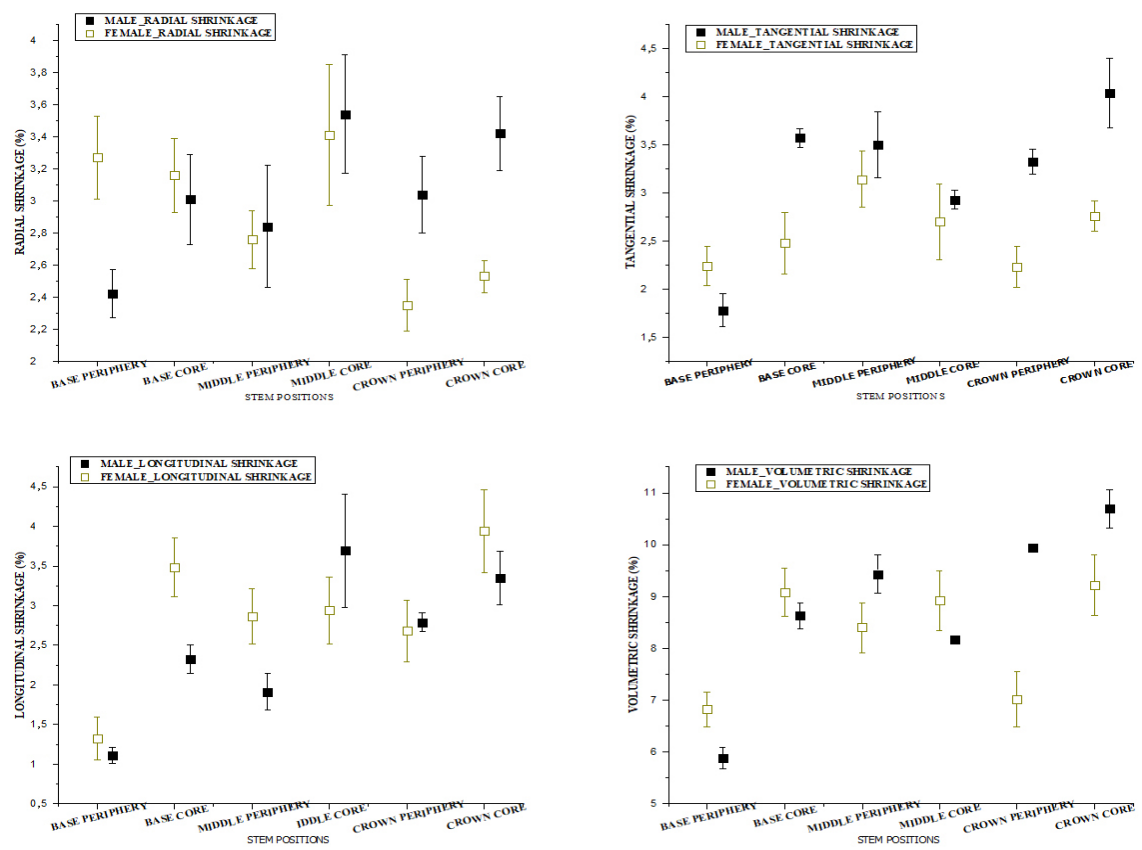

Figure 3: Shrinkage variabilities within the two Borassus aethiopum.

\section{Statistical analysis}

The analysis of variance (ANOVA) using Complete Randomized Design (CRD) was employed to assess the differences between the analysis using Origin Pro 8.5 software (2010). Subsequent Tukey's Honestly Significant Difference (HSD) tests were used to determine significant differences at the $5 \%$ probability level $\left(\operatorname{LSD}_{0,05}\right)$ to detect the means differences among all the assessed parameters. The mean differences within both varieties are presented in Table 1, Table 2, and Table 3 with standard deviations in brackets. Means that do not share a letter are significantly different. 
The peripheral from both varieties showed better physical characteristics in all cases. In most cases, significant differences exist radially. Generally, there was radial and axial variability in MC, density, and dimensional stability that confirms reports by cited researchers for palms, deciduous, and coniferous wood species. The lower MC, swelling, shrinkage but greater density at the peripheral portions along the bole can be ascribed to the presence of embedded vascular bundles, excessive lignin, and extractives content which create permanent aspirated voids at the peripheries than the cores. These inhabit porosity, moisture accumulation, maximize density, and mechanical characteristics that result in dermal rigidity, resistant to biodegradation, dimensionally stable, impermeable to moisture than cores particularly at the bases and middle of both varieties. This makes them more suitable for structural applications, especially in hazardous environments.

\section{CONCLUSIONS}

Unlike the cores, the two B. aethiopum varieties were heavy (density: $506 \mathrm{~kg} / \mathrm{m}^{3}-827 \mathrm{~kg} / \mathrm{m}^{3}$ ) and dimensionally stable along the peripheries up the bole: base (i.e., swelling $=4,51 \%-4,76 \%$; shrinkage: 5,88 $\%-6,82 \%)$, middle $(2,89 \%-4,75 \%$ and $8,40 \%-9,43 \%$ respectively) and crown $(3,82 \%-4,01 \%$ and $7,01 \%-9,93 \%$ respectively). Thus, the peripheries can be useful for structural works such as props, wooden bridges, and outdoor end-use products including garden furniture, flooring, rafters, ridges, lintels, and fences.

However, the cores could be employed for light product designs such as stool, cork for bottling, packaging, fencing, agricultural stakes, walking sticks, and pencils due to their lower density $\left(219,5 \mathrm{~kg} / \mathrm{m}^{3}-264 \mathrm{~kg} / \mathrm{m}^{3}\right)$ and excessive MC (61,31\% - 137,98 \%), which greatly influence the swelling (5,22 \% - 6,99\%) and shrinkage properties

Based on the superior qualities and stable dimensional changes of the peripheries, they can be used as structural materials for construction that would contribute to the reduction of the over-dependence and pressure on the primary timbers, increase the raw material base for the Wood Industry, and aid in sustaining the dwindling forests' biodiversity.

\section{ACKNOWLEDGMENTS}

Our profound appreciation to the staff of the Department of Wood Science and Technology, Faculty of Renewable Natural Resources (FRNR), Kwame Nkrumah University of Science and Technology, Kumasi, Ghana for their assistance. We also thank Ms. Agnes Ankomah Danso (Bio-Statistician, Crops Research Institute of CSIR, Kumasi) for the statistical guidance.

\section{REFERENCES}

Acheampong, J.B.; Effah, B.; Achana, E.W.; Antwi, K. 2020. The Effects of Chemical Compositional Variability on Sustainable Applications of Borassus aethiopum Trunks. IJFWS 7(2): 080-088. https://premierpublishers.org/ijfws/150520205108

Ajuziogu, G.C.; Amujiri, A.N.; Njoku1, E.U.; Ozokolie, C.B.; Ojua, E.O. 2020. Determination of Swelling and Dimensional Stability of Some Nigerian Timber Species. Annu Res Rev Biol 35(1): 24-29. https://doi.org/10.9734/arrb/2020/v35i130177

Akpan, M.; Anametemfiok, V.; Ijomah, J.U. 1999. Dimensional changes of wood in service: Potential of Eribroma Oblonga for interior decorations. J Techn Dev 7: 6-11.

Antwi, K. 2012. The variability between the strength and some physical properties of Allanblackia parviflora for furniture production. Master of Science Thesis, Department of Wood Science and Technology, Faculty of Renewable Natural Resources, Kwame Nkrumah University of Science and Technology, Kumasi, Ghana.

Arancon, R. 1997. Asia Pacific forestry sector outlook study: Focus on coconut wood. Food and Agricul-ture Organization of the United Nations. Working Paper No: APFSOS/WP/23.

http://www.fao.org/3/w7731e/w7731e00.htm 
Asafu-Adjaye, O. 2011. Characterization of the Physico-Mechanical properties of the different zones of Borassus aethiopum (Mmaa Kube). Master of Philosophy Thesis, Department of Wood Science and Technology, Faculty of Renewable Natural Resources, Kwame Nkrumah University of Science.

ASTM. 2006. Test methods for evaluating properties of wood-base fiber and particle panel materials. Linear expansion with change in moisture content. ASTM D1037-06a. ASTM: West Conshohocken, PA, USA

Ayarkwa, J. 1997. Potentials for Utilization of Borassus aethiopum (Fan palm) in construction in Ghana. Wood News 6(4): 15-18.

Bakar, E.S.; Hermawan, D.; Karlina, S.; Rachman, O.; Rosdiana, N. 1998. Utilization of oil palm trees as building and furniture material (1): physical and chemical properties and durability of oil palm trunk. Journal Teknologi Hasil Hutan 9(1): 1-12.

Belleville, B.; Lancelot, K.; Galore, E.; Ozarska, B. 2020. Assessment of physical and mechanical properties of Papua New Guinea timber species. Maderas-Cienc Tecnol 22(1): 3-12. http://dx.doi.org/10.4067/ S0718-221X2020005000101

Boadu, K.B.; Antwi-Boasiako, C.; Frimpong-Mensah, K. 2017. Physical and mechanical properties of Klainedoxa gabonesis with engineering potential. J For Res 28(3): 629-636. https://doi.org/10.1007/s11676016-0331-1

Bossu, J.; Beauchene, J.; Estevez, Y.; Duplais, C.; Clair, B. 2016. New Insight on Wood Dimensional Stability Influence by Secondary Metabolites: The Case of a Fast - Growing Tropical Species Bagassa guianensis Aubl. PLOS ONE 11(3): e0150777. https://doi.org/10.1371/journal.pone.0150777

Bowyer, L.J.; Shmulsky, R.; Haygreen, G.J. 2003. Forest Products and Wood Science. Blackwell Publishing Company: Iowa, U.S.A. $4^{\text {th }}$ Edition https://www.amazon.com/Forest-Products-Wood-Science-Introduction/dp/0813820367

Chamberlain, J.L.; Bush, R.J.; Hammett, A.L.; Araman, P.A. 2000. Managing national forests of the eastern United States for non-timber forest products. In Proceedings XXI IUFRO World Congress 2000, Forests and Society: The Role of Research 1: 407-420. https://www.fs.usda.gov/treesearch/pubs/1976

Eckelman, C.A. 2020. The shrinking and swelling of wood and its effect on furniture. Department of Forestry and Natural Resources, Purdue University: West Lafayette, IN. USA.

https://extension.purdue.edu/extmedia/FNR/FNR-163.pdf

Effah, B. 2012. Development of kiln-drying schedules and within tree variability in the physical properties of two lesser-known timber species in Ghana. Master of Science Thesis, Department of Wood Science and Technology, Faculty of Renewable Natural Resources, Kwame Nkrumah University of Science and Technology, Kumasi, Ghana. 163p.

Erwinsyah, S.H. 2008. Improvement of oil palm trunk properties using bio resin. Doctor of Philosophy Dissertation, Faculty of Environmental Sciences, Technische University Dresden, Germany. http://webdoc. sub.gwdg.de/ebook/dissts/Dresden/Erwinsyah2008.pdf

FAO. 1985. Coconut Wood Processing and Use. Rome, Italy. http://www.fao.org/3/an792e/an792e00.pdf

Fathi, L. 2014. Structural, mechanical properties and potential use of timber from coconut, oil and date palm trees. Doctor of Philosophy Thesis, Centre of Wood Science, University of Hamburg. Germany. https://ediss.sub.uni-hamburg.de/volltexte/2014/6922/pdf/Dissertation.pdf

Glass, S.V.; Zelinka, S.L. 2010. Moisture relations and physical properties of wood. Wood handbook: wood as an engineering material. chapter 4. Centennial ed. General technical report FPL; GTR - 190. Madison, WI: U.S. Dept. of Agriculture, Forest Service, Forest Product Laboratory, p. 4.1 - 4. 19.

https://www. fs.usda.gov/treesearch/pubs/37428

Gryc, V.; Horácek, P. 2007. Variability in density of spruce (Picea abies (L.) Karst.) Wood with the presence of reaction wood. J For Sci 53(3): 129-137. https://doi.org/10.17221/2146-JFS 
Jatau, D. 2008. Profitability Assessment of Borassus aethiopum (Mart) Marketing in Adamawa State, Nigeria. J Agri Soc Sci 4(4): 159-164.

Killman, W.; Choon, L.S. 1985. Anatomy and properties of oil palm stem. PORIM Bulliten 11, Institut Penyelidikan Minyak Kelapa Sawit Malaysia. p.25.

Kimberley, M.O.; McKinley, R.B.; Cown, D.J.; Moore, J.R. 2017. Modelling the variation in wood density of New Zealand-grown Douglas-fir. NZJ For Sci 47(15): 1-15. https://doi.org/10.1186/s40490-0170096-0

Kirk, K.T.; Culen, D. 1998. Enzymology and Molecular Genetics of Wood Degradation by White Rot Fungi. In Environmentally Friendly Technologies for the Pulp and Paper lndustry. Young, R.A., Akhtar, M. (editors). John Wiley \& Sons, Inc. Pp. 273 - 308. https://www.fpl.fs.fed.us/documnts/pdf1998/kirk98a.pdf

Kollmann, F.; Côté, W. 1984. Principles of wood science and technology. Volume I: Solid wood. Springer-Verlag: Berlin. Germany. https://link.springer.com/book/10.1007\%2F978-3-642-87928-9

Koubaa, A.; Hernandez, R.E.; Beaudoin, M.; Palanquin, J. 1998. Inter clonal and within - tree variation in fibre length of poplar hybrid clones. Wood Fiber Sci 30(1): 40-47. https://wfs.swst.org/index.php/wfs/ article/view/1990

Li, X.; Leavengood, S.; Cappellazzi, J.; Morrell, J.J. 2018. Laboratory decay resistance of Palmyra palm wood. Maderas-Cienc Tecnol 20(3): 353-358. http://dx.doi.org/10.4067/S0718-221X2018005003601

Lim, S.C.; Khoo, K. 1986. Characteristics of oil palm trunk and its potential utilization. The Malaysian Forester 49(1): 3-22.

Mantanis, G.I.; Young, R.A.; Rowell, R.M. 1994. Swelling of wood. Wood Sci Technol 28: 119-134. https://doi.org/10.1007/BF00192691

Millennium Seed Bank Project. 2007. Delivering Target 8 of the Global Strategy for Plant Conservation. https://www.kew.org/science/our-science/projects/banking-the-worlds-seeds

Origin software. 2010. Origin Pro 8.5 OriginLab Corporation. https://www.originlab.com/index.aspx?go $=$ Company/NewsAndEvents/PressRoom\&pid $=1720$

Panshin, A.J.; de Zeeuw, C. 1980. Textbook of Wood Technology: Structure, identification, properties, and uses of the commercial woods of the United States and Canada. 4th ed. McGraw-Hill Series in Forest Resources: New York, USA.

Phillips, O.L.; Sullivan, M.J.P.; Baker, T.R.; Mendoza, A.M.; Vargas, P.N.; Vásquez, R. 2019. Species Matter: Wood Density Influences Tropical Forest Biomass at Multiple Scales. Surv Geophys 40: 913-935. https://doi.org/10.1007/s10712-019-09540-0

Prayitno, T.A. 1995. Trunk shape and physical properties of oil palm trunk. Bulletin Fak. Publication Limited, London. 65p. In Proceedings from the World Conference on Timber Engineering, Quebec, Canada.

Shupe, T.F.; Choog, E.T.; Gibson, M.D. 1995. Differences in moisture content and shrinkage between outer wood, middle wood and core wood of two yellow Poplar trees. Forest Prod J 45(9): 85-90. https://euro-pepmc.org/article/agr/ind20509195

Timber Export Development Board. TEDB. 1994. Timber Export Development Board. Takoradi, Ghana and London, UK. 87p.

Tropenbos International-Ghana. 2005. Restoration and sustainable management of forest in Ghana. In Proceedings of Tropenbos International-Ghana Workshop Proceedings, Kumasi, Ghana Tropical Forest, Ghana, from July 5-7, 2005. https://www.tropenbos.org/resources/publications/restoration+and+sustainable + management + of + forests + in + ghana. + proceedings + of + an + international + conference + held + in + elmina, + ghana, + from + july $+5-7,+2005$. 
Watson, J.E.M.; Evans, T.; Venter, O.; Williams, B.; Tulloch, A.; Stewart, C. 2018. The exceptional value of intact forest ecosystems. Nat Ecol Evol 2: 599-610. https://www.nature.com/articles/s41559-0180490-x?proof $=$ trueIn\%EF\%BB\%BF 